\title{
Effect of extended colostrum feeding on plasma glucagon-like peptide-1 concentration in newborn calves
}

\author{
Y. Inabu, ${ }^{1}$ J. Pyo, ${ }^{2}$ S. Pletts, ${ }^{2}$ L. L. Guan, ${ }^{2}$ M. A. Steele, ${ }^{2 *}$ and T. Sugino ${ }^{1 *}$ \\ ${ }^{1}$ The Research Center for Animal Science, Graduate School of Biosphere Science, Hiroshima University, Higashi-Hiroshima, Japan 739-8528 \\ ${ }^{2}$ Department of Agricultural, Food and Nutritional Science, University of Alberta, Edmonton, Canada T6G 2P5
}

\begin{abstract}
Glucagon-like peptide-1 (GLP-1) plays a role in the regulation of glucose homeostasis via the stimulation of insulin secretion. The objective of this study was to evaluate the effect of extended colostrum feeding on plasma concentration of GLP-1. Holstein bull calves (n $=27$ ) were fed pooled colostrum at $7.5 \%$ of birth body weight at $2 \mathrm{~h}$ after birth and then fed mature milk (M), a 50:50 mixture of pooled colostrum and milk (CM), or pooled colostrum ( $\mathrm{C} ; \mathrm{n}=9$ for each treatment) at $5 \%$ of birth body weight at $12 \mathrm{~h}$ after birth and every 12 $\mathrm{h}$ thereafter until $72 \mathrm{~h}$ after birth. Blood samples were obtained before ( 1 and $2 \mathrm{~h}$ after birth) and after (until $72 \mathrm{~h}$ after birth; 42 time points) the first colostrum feeding, and plasma concentrations of glucose, insulin, and GLP-1 were measured. Data were analyzed by ANOVA of JMP 13 (SAS Institute Inc., Cary, NC) with treatment, time, and treatment $\times$ time interaction as fixed effects. Treatment $\times$ time interaction was observed for plasma insulin and glucose concentrations, which were mainly the result of lower concentrations from 1 to $2 \mathrm{~d}$ after birth for $\mathrm{C}$ compared with $\mathrm{M}$. Conversely, on d 3 after birth, the difference between treatments was not observed for insulin and glucose. For the entire experimental period, plasma GLP-1 concentration was higher for $\mathrm{C}(2.25 \mathrm{ng} / \mathrm{mL})$ compared with $\mathrm{M}(1.41 \mathrm{ng} / \mathrm{mL})$ and tended to be higher compared with CM (1.58 ng/ $\mathrm{mL})$. A treatment $\times$ time interaction was observed for GLP-1, but unlike glucose and insulin, this was mainly the result of higher concentrations from 54 to $72 \mathrm{~h}$ after birth (on d 3 after birth) for C compared with $\mathrm{M}$ or CM. Postprandial plasma concentration of glucose was not correlated with that of GLP-1 but was positively correlated with that of insulin for the 4-h period after feeding on $\mathrm{d} 1(\mathrm{r}=0.30)$ and $\mathrm{d} 3$ after birth $(\mathrm{r}=$ 0.33). Postprandial plasma concentration of GLP-1 was positively correlated with that of insulin for the 4-h
\end{abstract}

Received August 29, 2018.

Accepted December 28, 2018.

*Corresponding authors: masteele@ualberta.ca and sugino@ hiroshima-u.ac.jp period after feeding on $\mathrm{d} 3$ after birth $(\mathrm{r}=0.20)$. These results indicate that extended colostrum feeding may increase plasma GLP-1 concentrations, especially $3 \mathrm{~d}$ after birth, but further study is necessary to determine the effect on plasma insulin and glucose concentrations. Key words: glucagon-like peptide 1, glucose homeostasis, calf

\section{INTRODUCTION}

Glucose supplied by colostrum and milk intake is one of the essential energy sources for neonatal calves (Hammon et al., 2013). However, calves often develop marked hypoglycemia after birth that may negatively affect postnatal growth (Hammon and Blum, 1998; Bittrich et al., 2002; Steinhoff-Wagner et al., 2011b). As lactose supply from colostrum does not meet glucose demand in neonatal calves, glycogenolysis and gluconeogenesis are important metabolic pathways to establish postnatal euglycemia (Girard, 1986). However, fetal gluconeogenesis is low and maturation processes around birth are necessary to achieve sufficient endogenous glucose production (Girard, 1986; Girard et al., 1992; Fowden, 1997), as also seen in calves (Steinhoff-Wagner et al., 2011b). Thus, improving absorption of glucose from colostrum and milk is necessary to improve glucose status and growth in newborn calves.

Bovine colostrum contains not only immunoglobulin but also various bioactive factors such as growth factors, which promote gastrointestinal tract (GIT) development (Roy, 1980; Koldovský, 1989; Grosvenor et al., 1993). Hammon et al. (2013) reported that ingested colostrum enhanced glucose uptake via the improved absorptive capacity of the GIT. In addition, it has been reported that colostrum intake increased plasma concentration of insulin, which is involved in glucose homeostasis (Hammon et al., 2000; Inabu et al., 2018). In the previous study, amount, timing, and frequency of colostrum intake affected insulin secretion in calves (Hadorn et al., 1997; Hammon and Blum, 1998). Further, Hammon and Blum (1998) showed that extended duration of colostrum feeding positively affected plasma glucose and insulin concentrations in neonatal 
calves, indicating that extended colostrum feeding may affect glucose homeostasis via the alteration in blood hormone concentration.

Glucagon-like peptide-1 (GLP-1) is a gut-derived peptide secreted from intestinal L-cells in response to nutrient absorption from the intestine (Connor et al., 2015; Inabu et al., 2017, 2018). Glucagon-like peptide-1 is involved in glucose homeostasis via the stimulation of insulin secretion in both nonruminants (O'Halloran et al., 1990; Holz et al., 1993) and ruminants (Faulkner, 1991; Edwards et al., 1997; Fukumori et al., 2012) as well as its own direct action without mediating insulin action (Luque et al., 2002; Acitores et al., 2005; Sancho et al., 2005, 2006). In our previous study, we showed that plasma GLP-1 concentration increased in response to colostrum intake and that timing of the first colostrum feeding affected plasma concentration of GLP-1 as well as that of insulin (Inabu et al., 2018).

However, to our knowledge, the effect of extended colostrum feeding on plasma GLP-1 concentration has not been determined. Given that insulin is affected by extended colostrum feeding, it is possible that extended duration of colostrum feeding affects plasma GLP-1 concentration in neonatal calves. We hypothesized that extended colostrum feeding may increase plasma GLP1 , insulin, and glucose concentrations. Our objective was to evaluate the effect of extended colostrum feeding on plasma concentration of GLP-1, glucose, and insulin in newborn calves.

\section{MATERIALS AND METHODS}

\section{Animals and Diets}

All experimental procedures used in this study were approved by the University of Alberta Animal Care and Use Committee for Livestock and conducted in accordance with the guidelines of the Canadian Council of Animal Care (Ottawa, ON, Canada). A total of 27 Holstein bull calves used for the present study were obtained from the Dairy Research and Technology Centre of the University of Alberta (Edmonton, AB, Canada). All calves had no health problems (high or low body temperature and abnormal feces) and were not excluded from the present study. Calves were born as singlets and separated from their dams at birth and then managed in individual pens, which were all inside the barns. The pens were bedded with shavings on the bottom layer and fresh straw on the top layer. Regardless of treatment groups, all calves were fed pooled colostrum containing $62 \mathrm{~g}$ of IgG/L (Saskatoon Colostrum Co. Ltd., Saskatoon, SK, Canada) at $7.5 \%$ of birth BW at $2 \mathrm{~h}$ after birth using a nipple bottle. Thereafter, calves were randomly assigned to 1 of 3 treatments - pooled whole milk obtained from cows in the Dairy Research and Technology Center (M), a 50:50 mixture of pooled colostrum and pooled whole milk (CM; to mimic transition milk), and pooled colostrum (C) - and were fed at $5 \%$ of birth BW at $12 \mathrm{~h}$ after birth and every 12 $\mathrm{h}$ thereafter until $72 \mathrm{~h}$ after birth. Calves were given access to water but not any other diets during the experimental period. The DM, total fat, total protein, lactose, and MUN contents for the whole milk were $13.2 \%, 5.2 \%, 3.0 \%, 4.0 \%$, and $14.2 \mathrm{mg} / \mathrm{dL}$, respectively, and those for the colostrum were $23.0 \%, 4.6 \%, 13.1 \%$, $2.8 \%$, and $34.4 \mathrm{mg} / \mathrm{dL}$, respectively. Calves were fed treatment meals by bottle initially, but if the calves did not consume all the meal within $30 \mathrm{~min}$, they were tube-fed the remainder of the meal volume. Pooled whole milk and colostrum were bagged and then were frozen at $-20^{\circ} \mathrm{C}$ until thawing. Before feeding, the whole milk and colostrum were taken out of the freezer and thawed in a water bath at a consistent temperature of $60^{\circ} \mathrm{C}$ until the milk reached a temperature of $39^{\circ} \mathrm{C}$.

\section{Sample Collection}

Blood samples were taken within $1 \mathrm{~h}$ after birth using evacuated tubes (Fisher Scientific, Nepean, ON, Canada) and at $2 \mathrm{~h}$ after birth through the jugular catheter (Thermo Fisher Scientific, San Diego, CA), which were fitted before first colostrum feeding, as the baseline samples. After the baseline blood sampling, blood samples were collected at 3,6, 9, and $11 \mathrm{~h}$ after birth; every 30 min from 12 to $16 \mathrm{~h}$ after birth (for a 4-h period after feeding on d 1); every $1 \mathrm{~h}$ from 17 to 24 $\mathrm{h}$ after birth; 27, 30, 36, 42, 48, 54, and $59 \mathrm{~h}$ after birth; every 30 min from 60 to $64 \mathrm{~h}$ after birth (for a 4 -h period after feeding on $\mathrm{d} 3$ ); and $65,66,68,70,72$, and 75 $\mathrm{h}$ after birth. The blood samples collected at 12, 24, 30, $36,48,60$, and $72 \mathrm{~h}$ after birth were taken immediately before the treatment diet feeding. Immediately after sample collection, aprotinin (Sigma-Aldrich, St. Louis, MO) was added to the blood samples for plasma preparation (in the ratio of 500 kallikrein inhibitor units $/ \mathrm{mL}$ of blood). Blood samples were centrifuged at 3,000 $\times \mathrm{g}$ and $4^{\circ} \mathrm{C}$ for $20 \mathrm{~min}$, and the plasma was collected and stored at $-20^{\circ} \mathrm{C}$ until analysis.

\section{Sample Analysis}

Plasma samples were analyzed for hormone and glucose concentrations. Plasma hormone concentrations were measured following the time-resolved fluoroimmunoassay technique, which was previously described by Sugino et al. (2004). Plasma GLP-1 concentration was measured using a solid-phase competition immunoassay with europium-labeled human GLP-1 and polystyrene 
microtiter strips (Nalgene Nunc Int., Tokyo, Japan) coated with anti-rabbit $\gamma$-globulin (Inabu et al., 2017). Intra- and interassay coefficients of variation were 4.7 and $5.3 \%$, respectively, and the least detectable level was $0.007 \mathrm{ng} / \mathrm{mL}$. The plasma concentration of insulin was measured using a solid-phase competition immunoassay with europium-labeled bovine insulin and polystyrene microtiter strips coated with anti-guinea pig $\gamma$-globulin (Inabu et al., 2017). Intra- and interassay coefficients of variation were 2.1 and $3.1 \%$, respectively, and the least detectable level was $0.14 \mathrm{ng} / \mathrm{mL}$. Plasma glucose concentration was analyzed using an enzymatic method with peroxidase glucose oxidase (Sigma-Aldrich).

\section{Statistical Analysis}

Data for plasma glucose, GLP-1, and insulin concentrations were analyzed using the fit model procedure of JMP 13 (SAS Institute Inc., Cary, NC) for 3 phases: the entire experimental period (1-72 $\mathrm{h}$ after birth), a 4-h period after feeding on d 1 (12-16 h after birth), and a 4-h period after feeding on d 3 (60-64 h after birth). Data were analyzed according to the following model:

$$
\mathrm{Y}_{\mathrm{ijk}}=\mu+\mathrm{T}_{\mathrm{i}}+\mathrm{H}_{\mathrm{j}}+\mathrm{C}_{\mathrm{k}}+\mathrm{TH}_{\mathrm{ij}}+\mathrm{e}_{\mathrm{ijk}},
$$

where $Y_{i j k}$ is the dependent variable, $\mu$ is the overall mean, $T_{i}$ is the fixed effect of treatment, $H_{j}$ is the fixed effect of time after birth used as a repeated measure, $\mathrm{C}_{\mathrm{k}}$ is the random effect of the calf, and $\mathrm{e}_{\mathrm{ijk}}$ is the error term.

The nutrient intake (fat, protein, lactose, and MUN) for each treatment and the area under the curve (AUC) of plasma glucose, insulin, and GLP-1 concentrations for the entire experimental period $\left(\mathbf{A} \mathbf{U} \mathbf{C}_{\mathbf{1 - 7 2}}\right)$ were calculated and analyzed according to the following model:

$$
\mathrm{Y}_{\mathrm{ij}}=\mu+\mathrm{T}_{\mathrm{i}}+\mathrm{C}_{\mathrm{j}}+\mathrm{e}_{\mathrm{ij}},
$$

where $\mathrm{Y}_{\mathrm{ij}}$ is the dependent variable, $\mu$ is the overall mean, $\mathrm{T}_{\mathrm{i}}$ is the fixed effect of treatment, $\mathrm{C}_{\mathrm{j}}$ is the random effect of the calf, and $e_{i j}$ is the error term. In addition, the AUC of plasma glucose and hormone concentrations for a 4 -h period after feeding on d 1 $\left(\mathbf{A U C}_{\mathbf{1 2 - 1 6}}\right)$ and d 3 (AUC $\left.\mathbf{C}_{\mathbf{6 0 - 6 4}}\right)$ were analyzed according to the following model:

$$
\mathrm{Y}_{\mathrm{ijk}}=\mu+\mathrm{T}_{\mathrm{i}}+\mathrm{D}_{\mathrm{j}}+\mathrm{C}_{\mathrm{k}}+\mathrm{TD}_{\mathrm{ij}}+\mathrm{e}_{\mathrm{ijk}},
$$

where $Y_{i j k}$ is the dependent variable, $\mu$ is the overall mean, $T_{i}$ is the fixed effect of treatment, $D_{j}$ is the fixed effect of day after birth (d 1 vs. d 3), $C_{k}$ is the random effect of the calf, and $e_{\mathrm{ijk}}$ is the error term. All values were expressed as least squares means \pm standard error of the mean. The effects of treatment, time, and treatment $\times$ time interaction were considered significant at $P<0.05$, and tendencies were assumed at $0.05 \leq$ $P<0.10$. Pearson correlation coefficients $(\mathrm{r})$ between plasma glucose, insulin, and GLP-1 concentrations were analyzed for the 4-h period after feeding on $\mathrm{d} 1$ and 3 to evaluate the relationship after feeding.

\section{RESULTS}

The intake of treatment diets and nutrients per meal for each treatment group is shown in Table 1. The treatment diet intake was not different between treatments as birth BW was not different across treatment groups $(43.8 \pm 1.65,41.4 \pm 1.85$, and $42.3 \pm 1.65 \mathrm{~kg}$ for $\mathrm{M}, \mathrm{CM}$, and $\mathrm{C}$, respectively; $P>0.10$ ). The total protein and MUN contents were much higher and lactose content was lower for the pooled colostrum than for the whole milk, consistent with the values shown in previous studies (Hammon and Blum, 1998; Desjardins-Morrissette et al., 2018). This resulted in a higher protein and MUN intake and a lower lactose intake for $\mathrm{C}$ calves than for $\mathrm{M}$ calves and intermediate values for CM calves. The total fat content was lower for the colostrum than for the whole milk, which resulted in a lower fat intake for $\mathrm{C}$ and $\mathrm{CM}$ calves compared with M calves.

Regardless of dietary treatment, a time effect was observed in plasma glucose concentration for the entire experimental period $(P<0.01)$ and the 4 -h period after

\begin{tabular}{|c|c|c|c|c|c|}
\hline \multirow[b]{2}{*}{ Item } & \multicolumn{3}{|c|}{ Treatment } & \multirow[b]{2}{*}{ SEM } & \multirow[b]{2}{*}{$P$-value } \\
\hline & M & $\mathrm{CM}$ & $\mathrm{C}$ & & \\
\hline Treatment diet intake, $\mathrm{kg} /$ meal & 2.23 & 2.06 & 2.11 & 0.92 & 0.30 \\
\hline Fat intake, $\mathrm{g} /$ meal & $121^{\mathrm{a}}$ & $105^{\mathrm{b}}$ & $100^{\mathrm{b}}$ & 4.5 & $<0.01$ \\
\hline Protein intake, g/meal & $70^{\mathrm{c}}$ & $172^{\mathrm{b}}$ & $284^{\mathrm{a}}$ & 8.3 & $<0.01$ \\
\hline Lactose intake, $\mathrm{g} /$ meal & $93^{\mathrm{a}}$ & $73^{\mathrm{b}}$ & $61^{\mathrm{c}}$ & 3.1 & $<0.01$ \\
\hline MUN intake, mg/meal & $317^{\mathrm{c}}$ & $501^{\mathrm{b}}$ & $728^{\mathrm{a}}$ & 22.9 & $<0.01$ \\
\hline
\end{tabular}

Table 1. Intake of treatment diets and nutrients per meal for calves fed milk (M), a 50:50 mixture of milk and colostrum $(\mathrm{CM})$, or colostrum $(\mathrm{C})$

${ }^{\mathrm{a}-\mathrm{c}}$ Treatment effects within a row with different superscripts differ $(P<0.05)$. 
feeding on $\mathrm{d} 1(P<0.01)$ and $\mathrm{d} 3(P<0.01$; Figure $1 \mathrm{~A}$; Table 2). The $\mathrm{AUC}_{60-64}$ for glucose concentration was higher $(P<0.05)$ than $\mathrm{AUC}_{12-16}$ for $\mathrm{C}$ and tended to be higher than $\mathrm{AUC}_{12-16}$ for $\mathrm{M}$ and $\mathrm{CM}(0.05<P<$ 0.10; Table 3) within a treatment group. For the entire experimental period, treatment $\times$ time interaction was observed in glucose concentration $(P<0.01)$, which was mainly the result of lower concentration for $\mathrm{C}$ than for $\mathrm{M}$ from 14 to $16 \mathrm{~h}$ after birth and at 27,30 , and 48 $\mathrm{h}$ after birth. However, no difference was observed for glucose concentration between treatments at any time points on d 3. Similarly, $\mathrm{AUC}_{12-16}$ tended to be higher $(P<0.01)$ for $\mathrm{M}(103.4 \pm 5.1 \mathrm{mg} / \mathrm{dL} \times \mathrm{h})$ than for $\mathrm{C}(86.0 \pm 5.4 \mathrm{mg} / \mathrm{dL} \times \mathrm{h})$, whereas $\mathrm{AUC}_{60-64}$ did not differ across treatments.

Regardless of dietary treatments, time effect was observed in plasma insulin concentrations for the entire experimental period $(P<0.01)$ and the 4 -h period after feeding on d $1(P<0.01)$ and $\mathrm{d} 3(P<0.01$; Figure 1B; Table 2), which was the result of increased plasma concentration in response to feeding. The fluctuation of plasma insulin was similar to that of plasma glucose concentration, and a positive correlation was observed between plasma insulin and glucose concentrations at the 4 -h period after feeding on $\mathrm{d} 1(\mathrm{r}=0.30, P<0.01$; Figure 2A) and d $3(\mathrm{r}=0.33, P<0.01$; Figure $2 \mathrm{D})$. For plasma insulin concentration, $\mathrm{AUC}_{60-64}$ was significantly lower $(P<0.05$; Table 3$)$ than $\mathrm{AUC}_{12-16}$ for $\mathrm{M}$ and $\mathrm{CM}$ within a treatment group, whereas the difference between $\mathrm{AUC}_{12-16}$ and $\mathrm{AUC}_{60-64}$ was relatively smaller for $\mathrm{C}$ compared with $\mathrm{M}$ or $\mathrm{CM}(0.05<P<$ $0.10)$. Treatment $\times$ time interaction was observed $(P<$ $0.01)$ for insulin concentration for the entire experimental period, which was the result of lower concentration for $\mathrm{C}$ than for $\mathrm{M}$ from 13 to $16 \mathrm{~h}$ after birth and at $27 \mathrm{~h}$ after birth. Similar to glucose concentration, there was no difference between treatments at any time points on d 3. Similarly, for insulin concentration, $\mathrm{AUC}_{12-16}$ for $\mathrm{M}$ was higher $(P<0.01)$ than that for $\mathrm{C}$, and that for $\mathrm{CM}$ was intermediate, whereas $\mathrm{AUC}_{60-64}$ did not differ across treatments.

Regardless of dietary treatments, a time effect was observed for plasma GLP-1 concentration for the entire experimental period $(P<0.01)$ and the 4 -h period after feeding on d 1 ( $P=0.02$; Figure $1 \mathrm{C}$; Table 2$)$. However, unlike glucose and insulin, plasma GLP-1 concentration did not increase in response to feeding on $\mathrm{d} 3$. For GLP-1, AUC $_{60-64}$ was higher $(P<0.05$; Table 3$)$ than $\mathrm{AUC}_{12-16}$ for $\mathrm{C}$ and tended to be higher $(0.05<P<$ 0.10) than $\mathrm{AUC}_{12-16}$ for $\mathrm{CM}$ within a treatment group. On the other hand, no difference between $\mathrm{AUC}_{12-16}$ and $\mathrm{AUC}_{60-64}$ was observed for M. For the entire experimental period, plasma GLP-1 concentration was higher (treatment $P<0.05$; Table 2) for $\mathrm{C}$ than for $\mathrm{M}$ and tended to be higher $(0.05<P<0.10)$ for $\mathrm{CM}$ than for $\mathrm{M}$ and for $\mathrm{C}$ than for CM. Treatment $\times$ time interaction was observed for GLP-1 concentration $(P<0.01)$, which was the result of higher GLP-1 concentration at all time points on $\mathrm{d} 3$ for $\mathrm{C}$ than for $\mathrm{M}$ and $\mathrm{CM}$. However, the difference between treatments was not observed at any time points on $\mathrm{d} 1$ and 2. Similarly, $\mathrm{AUC}_{1-72}$ and $\mathrm{AUC}_{60-64}$ were higher $(P<0.01)$ for $\mathrm{C}$ than for $\mathrm{M}$ and CM. Although no significant correlation was observed for the 4-h period after feeding on d 1, plasma concentration of GLP-1 was positively correlated with that of insulin for the 4-h period after feeding on $\mathrm{d} 3(\mathrm{r}$ $=0.20, P<0.01 ;$ Figure $2 \mathrm{~F})$.

\section{DISCUSSION}

The objective of this study was to evaluate the effect of extended duration of colostrum feeding on plasma glucose, insulin, and GLP-1 concentrations in neonatal calves. In the present study, we showed for the first time that extended colostrum feeding increased plasma GLP-1 concentration on d 3 after birth. In the present study, plasma glucose and insulin concentrations were lower for $\mathrm{C}$ calves than for $\mathrm{M}$ calves on 1 and $2 \mathrm{~d}$ after birth; this is inconsistent with previous findings by Hammon and Blum (1998), who reported a tendency for greater plasma insulin concentration on d 2 after birth for the calves fed colostrum twice daily for $3 \mathrm{~d}$ but not for the calves fed colostrum once at the first feeding compared with the calves fed only milk replacer instead of colostrum. Unlike the study by Hammon and Blum (1998), all calves were fed colostrum at the first feeding, which might produce different results between the previous study and the present study.

Fluctuation of plasma glucose concentration was similar to that of plasma insulin concentration, and a positive correlation between glucose and insulin was observed for the 4 -h period after feeding on both $\mathrm{d}$ 1 and $\mathrm{d} 3$. Therefore, it is indicated that the increase in insulin concentration after feeding is attributed to enhanced endogenous production stimulated by blood glucose in this study. Several studies reported that plasma insulin concentrations were increased after intake of colostrum, milk replacer, milk-based formula, or glucose, indicating that nutrient intake, especially glucose intake, stimulates insulin secretion (Hadorn et al., 1997; Hammon and Blum, 1998; Rauprich et al., 2000; Nussbaum et al., 2002), consistent with the present study. Similar to the findings of previous studies (Hammon and Blum, 1998), plasma glucose and insulin concentrations at some time points after the second and third feedings were greater for $\mathrm{M}$ than for $\mathrm{C}$.

As mentioned previously, lactose intake was greater for $\mathrm{M}$ than for $\mathrm{C}$. Thus, greater glucose and insulin con- 
$\mathbf{A}$

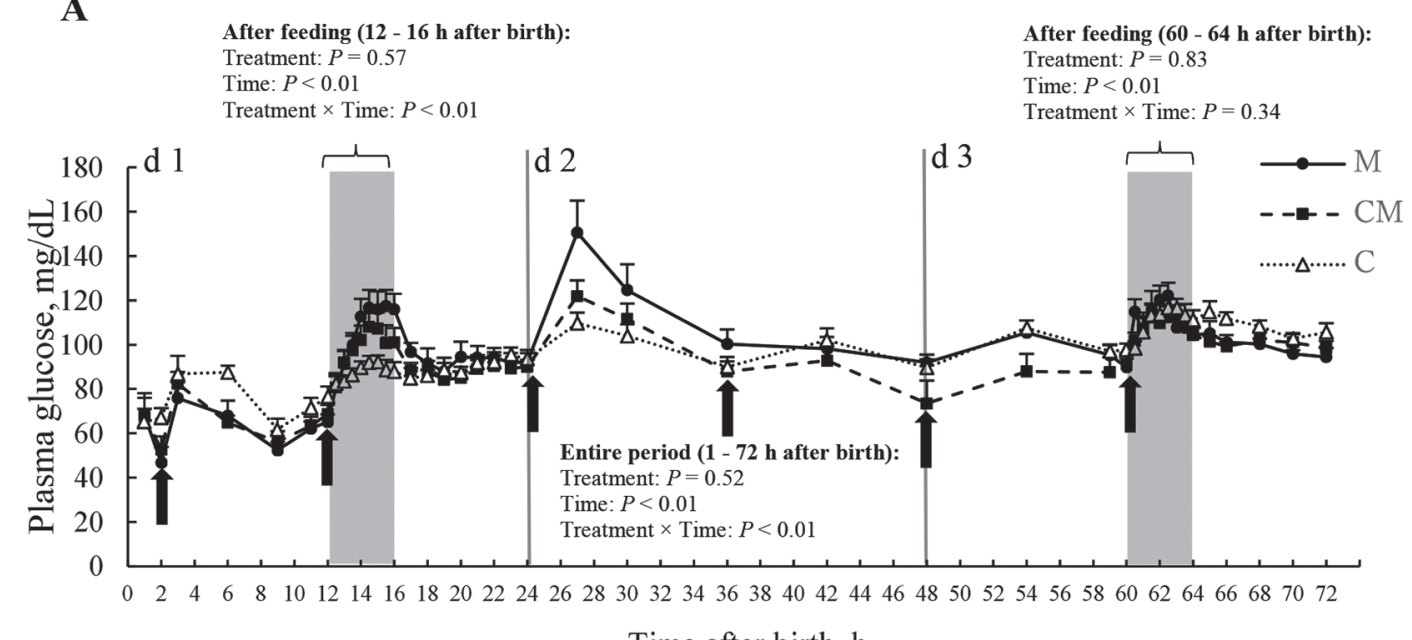

Time after birth, $h$

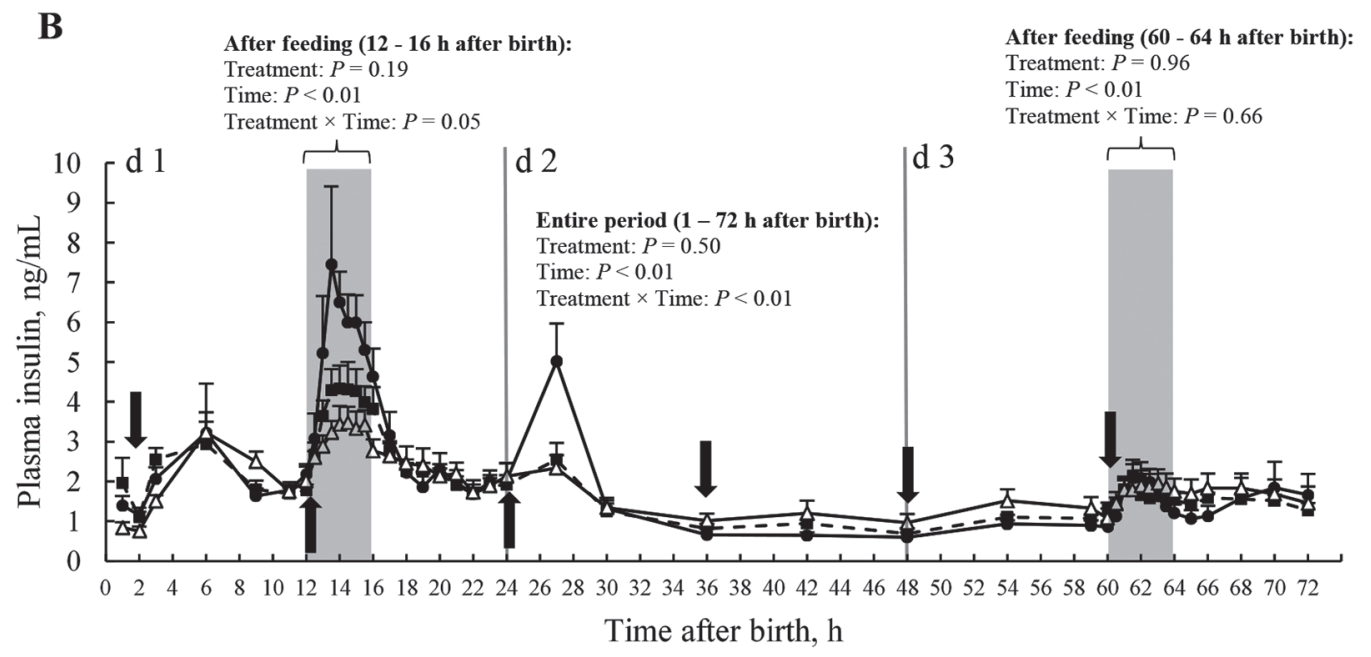

C

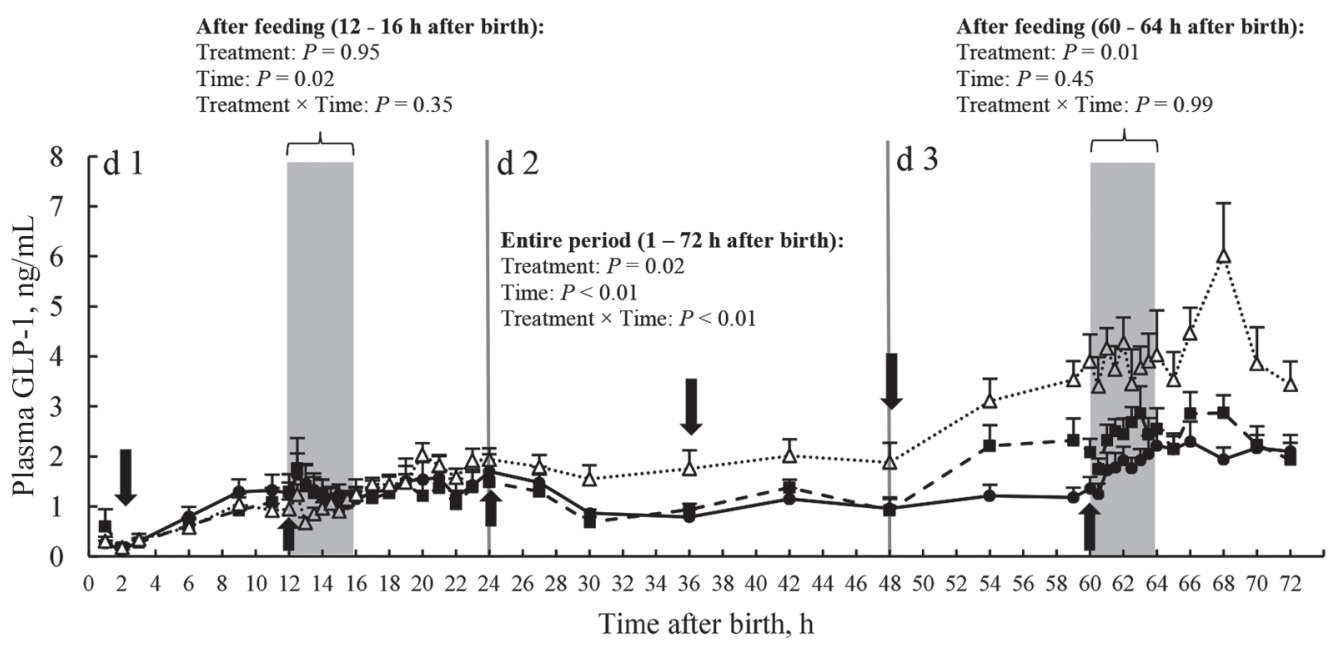

Figure 1. Plasma concentrations (LSM $\pm \mathrm{SEM})$ of $(\mathrm{A})$ glucose $(\mathrm{mg} / \mathrm{dL})$, (B) insulin (ng/mL), and (C) glucagon-like peptide-1 (GLP-1; ng/ $\mathrm{mL}$ ) for calves fed pooled colostrum at $2 \mathrm{~h}$ after birth and then fed mature milk (M), a 50:50 mixture of pooled colostrum and milk (CM), or pooled colostrum (C) at $12 \mathrm{~h}$ after birth and every $12 \mathrm{~h}$ thereafter until $72 \mathrm{~h}$ after birth. Arrows show feeding. 
Table 2. Plasma concentrations of glucose, insulin, and glucagon-like peptide-1 (GLP-1) for calves fed milk (M), a 50:50 mixture of milk and colostrum $(\mathrm{CM})$, or colostrum $(\mathrm{C})$

\begin{tabular}{|c|c|c|c|c|c|c|c|}
\hline Item $^{1}$ & \multicolumn{3}{|c|}{ Treatment } & SEM & \multicolumn{3}{|c|}{$P$-value for fixed effect ${ }^{2}$} \\
\hline Entire period & 97.2 & 92.7 & 93.3 & 3.0 & 0.52 & $<0.01$ & $<0.01$ \\
\hline After feeding on d 1 & 101.6 & 95.3 & 85.5 & 9.3 & 0.57 & $<0.01$ & $<0.01$ \\
\hline After feeding on d 3 & 110.0 & 106.7 & 107.8 & 6.2 & 0.83 & $<0.01$ & 0.34 \\
\hline \multicolumn{8}{|l|}{ Plasma insulin, $\mathrm{ng} / \mathrm{mL}$} \\
\hline After feeding on d 3 & 1.58 & 1.64 & 1.71 & 0.31 & 0.96 & $<0.01$ & 0.66 \\
\hline \multicolumn{8}{|l|}{ Plasma GLP-1, ng/mL } \\
\hline Entire period & $1.40^{\mathrm{b}}$ & $1.57^{\mathrm{ab}}$ & $2.22^{\mathrm{a}}$ & 0.19 & 0.02 & $<0.01$ & $<0.01$ \\
\hline After feeding on d 1 & 1.30 & 1.25 & 0.98 & 0.51 & 0.94 & 0.02 & 0.35 \\
\hline After feeding on d 3 & $1.79^{\mathrm{b}}$ & $2.39^{\mathrm{ab}}$ & $2.95^{\mathrm{a}}$ & 0.34 & 0.01 & 0.45 & 0.99 \\
\hline
\end{tabular}

${ }^{\mathrm{a}, \mathrm{b}}$ Treatment effects within a row with different superscripts differ $(P<0.05)$.

${ }^{1}$ Entire period $=1$ to $72 \mathrm{~h}$ after birth; $\mathrm{d} 1=12$ to $16 \mathrm{~h}$ after birth; $\mathrm{d} 3=60$ to $64 \mathrm{~h}$ after birth.

${ }^{2} \mathrm{~T}=$ treatment; time $=$ hours after birth; $\mathrm{T} \times$ time $=$ treatment $\times$ time interaction.

centrations for $\mathrm{M}$ may be mainly the result of greater lactose intake for $\mathrm{M}$ calves than for $\mathrm{C}$ calves in the present study in accordance with the results of our previous study (Inabu et al., 2018). In contrast to previous studies (Hammon and Blum, 1998), greater plasma glucose and insulin concentrations for $\mathrm{C}$ were not observed in the present study. However, plasma concentrations on d 3 and $\mathrm{AUC}_{60-64}$ for glucose and insulin did not differ across treatments despite the higher lactose content for mature milk compared with colostrum. Furthermore, for plasma glucose concentration, $\mathrm{AUC}_{60-64}$ was significantly higher than $\mathrm{AUC}_{12-16}$ in $\mathrm{C}$ but not significant in $\mathrm{M}$ and $\mathrm{CM}$ within a treatment group. Although insulin $\mathrm{AUC}_{12-16}$ was higher than $\mathrm{AUC}_{60-64}$ for $\mathrm{M}$ and
$\mathrm{CM}$, the difference between $\mathrm{AUC}_{12-16}$ and $\mathrm{AUC}_{60-64}$ was smaller for $\mathrm{C}$ compared with other treatments. It has been reported that ingested colostrum stimulates the development and function of the GIT in neonatal calves (Bühler et al., 1998; Blum and Hammon, 2000). In addition, Hammon and Blum (1998) reported that a postprandial increase in plasma glucose concentration for calves fed colostrum for $3 \mathrm{~d}$ after birth was greater on d 2 of age than on d 1 of age, whereas there was no difference between $\mathrm{d} 1$ and 2 for the calves fed only milk, which was attributed to enhanced glucose absorption from the intestine by positive effect of colostrum feeding. Similar to these findings, villus height in the jejunum and ileum was significantly greater for $\mathrm{CM}$ and

Table 3. Area under the curve (AUC) for plasma glucose, insulin, and glucagon-like peptide-1 (GLP-1) concentrations for calves fed milk (M), a 50:50 mixture of milk and colostrum (CM), or colostrum (C)

\begin{tabular}{|c|c|c|c|c|c|}
\hline \multirow[b]{2}{*}{ Item $^{1}$} & \multicolumn{3}{|c|}{ Treatment } & \multirow[b]{2}{*}{ SEM } & \multirow[b]{2}{*}{$P$-value ${ }^{2}$} \\
\hline & M & $\mathrm{CM}$ & $\mathrm{C}$ & & \\
\hline \multicolumn{6}{|c|}{ Glucose, $\mathrm{mg} / \mathrm{dL} \times \mathrm{h}$} \\
\hline $\mathrm{AUC}_{1-72}$ & 93.3 & 88.1 & 91.2 & 3.4 & 0.56 \\
\hline $\mathrm{AUC}_{12-16}$ & $103.5^{*}$ & $96.8^{*}$ & $86.0^{* *}$ & 3.6 & 0.08 \\
\hline $\mathrm{AUC}_{606}$ & 113.4 & 107.9 & 108.6 & 4.4 & 0.63 \\
\hline \multicolumn{6}{|c|}{ Insulin, $\mathrm{ng} / \mathrm{mL} \times \mathrm{h}$} \\
\hline $\mathrm{AUC}_{1-72}$ & 1.69 & 1.61 & 1.69 & 0.18 & 0.94 \\
\hline $\mathrm{AUC}_{12-16}$ & $5.59^{* *}$ & $3.83^{* *}$ & $3.10^{*}$ & 0.56 & 0.02 \\
\hline $\mathrm{AUC}_{60-64}$ & 1.70 & 1.67 & 1.76 & 0.24 & 0.96 \\
\hline \multicolumn{6}{|c|}{ GLP-1, $109 / \mathrm{mL} \times \mathrm{h}$} \\
\hline $\mathrm{AUC}_{1-72}$ & $1.23^{\mathrm{b}}$ & $1.42^{\mathrm{b}}$ & $2.13^{\mathrm{a}}$ & 0.18 & $<0.01$ \\
\hline $\mathrm{AUC}_{12-16}$ & 1.29 & 1.26 & $0.97^{* *}$ & 0.27 & 0.67 \\
\hline $\mathrm{AUC}_{60-64}$ & $1.83^{\mathrm{b}}$ & $2.39^{\mathrm{b}}$ & $3.94^{\mathrm{a}}$ & 0.32 & $<0.01$ \\
\hline \multicolumn{6}{|c|}{$\overline{\mathrm{a}, \mathrm{b}}$ Treatment effects within a row with different superscripts differ $(P<0.05)$. } \\
\hline \multirow{2}{*}{\multicolumn{6}{|c|}{$\begin{array}{l}{ }^{1} \mathrm{AUC}_{1-72}, \mathrm{AUC}_{12-16} \text {, and } \mathrm{AUC}_{60-64} \text { are the } \mathrm{AUC} \text { calculated for the entire experimental period, from } 12 \text { to } 16 \\
\text { after birth, and from } 60 \text { to } 64 \mathrm{~h} \text { after birth, respectively. } \\
{ }^{2} P \text {-value for fixed effect of treatment. }\end{array}$}} \\
\hline & & & & & \\
\hline \multicolumn{6}{|c|}{$\begin{array}{l}* 0.05<P<0.10 \text { between } \mathrm{AUC}_{12-16} \text { and } \mathrm{AUC}_{60-64} \text { within a treatment group. }{ }^{* *} P<0.05 \text { between } \mathrm{AUC}_{12-16} \text { an } \\
\text { AUC }_{60-64} \text { within a treatment group. }\end{array}$} \\
\hline
\end{tabular}



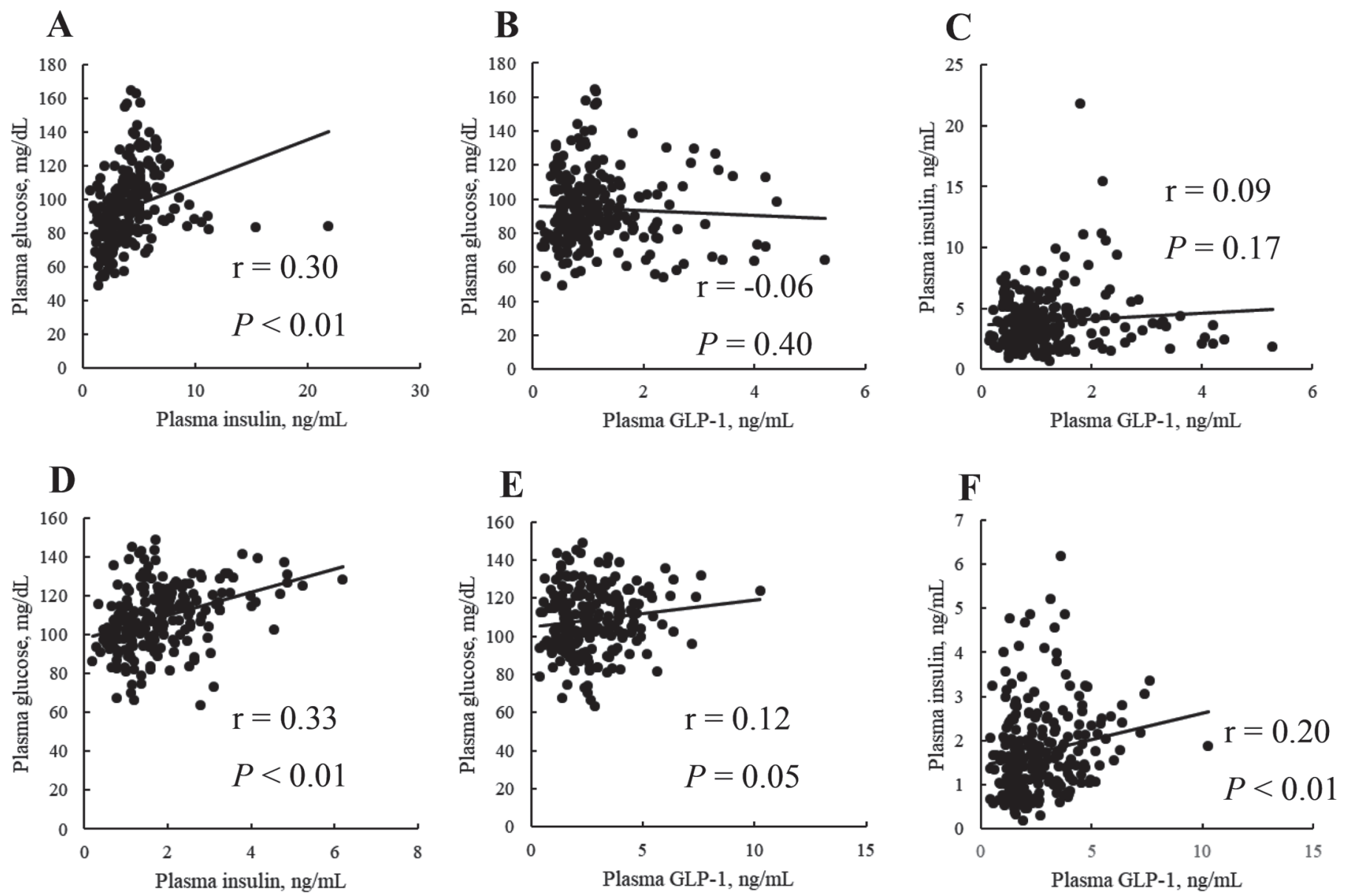

Figure 2. Pearson correlation coefficient $(\mathrm{n}=27)$ between plasma concentrations of glucose, insulin, and glucagon-like peptide-1 (GLP-1) for a 4 -h period after feeding on $(\mathrm{A}-\mathrm{C}) \mathrm{d} 1$ and $(\mathrm{D}-\mathrm{F}) \mathrm{d} 3$.

C compared with $\mathrm{M}$ in the present study (data not shown), indicating that extended colostrum or a mixture of whole milk and colostrum feeding may improve GIT development in newborn calves. It is possible that enhanced glucose absorption due to greater intestinal surface area for $\mathrm{C}$ compensates for the lower lactose content in the diet and stimulates insulin secretion, which presumably resulted in no difference between treatments for glucose and insulin concentrations on d 3 in the present study. Therefore, although plasma glucose and insulin concentrations were not different on $\mathrm{d} 3$ or lower for $\mathrm{C}$ on $\mathrm{d} 1$, it is speculated that extended colostrum feeding may positively affect glucose absorption and insulin secretion on $\mathrm{d} 3$ of age via the enhanced development of intestinal epithelium. Steinhoff-Wagner et al. (2011a) reported that colostrum-fed calves had higher plasma glucose concentrations compared with formula-fed calves, although lactose intake was similar in colostrum- and formula-fed calves. Furthermore, in the study by Steinhoff-Wagner et al. (2011a), the enrichment of $\left[\mathrm{U}_{-}{ }^{13} \mathrm{C}\right]$-glucose from milk was clearly greater in formula-fed calves than in colostrum-fed calves, indicating that lactose uptake may be enhanced in the calves fed colostrum compared with the calves fed formula. Further, it was reported that xylose was more absorbed in colostrum-fed calves than in calves fed milk replacer or formula (Hammon and Blum, 1997; Rauprich et al., 2000; Blum, 2006). These previous studies indicate that lactose uptake from the small intestine may be enhanced in colostrum-fed calves compared with calves fed milk replacer or formula, similar to the findings of the present study. Further investigation is necessary to evaluate the long-term effects of extended colostrum feeding on plasma concentrations of glucose and insulin.

In the present study, we showed for the first time that prolonged colostrum feeding increases plasma GLP-1 concentration, especially on d 3 after birth. Although a time effect was observed for all of the treatments, plasma GLP-1 concentration gradually increased with increasing age to a greater extent for $\mathrm{C}$ compared with $\mathrm{M}$ or $\mathrm{CM}$, which resulted in greater $\mathrm{AUC}_{60-64}$ compared 
with $\mathrm{AUC}_{12-16}$ within treatment $\mathrm{C}$ and greater $\mathrm{AUC}_{60-64}$ for $\mathrm{C}$ than for $\mathrm{M}$ or $\mathrm{CM}$. Glucagon-like peptide- 1 is secreted from enteroendocrine L-cells in response to luminal nutrients absorption from intestinal cells (Connor et al., 2015; Inabu et al., 2017, 2018). As mentioned previously, colostrum intake stimulates GIT development via the stimulation of intestinal cell proliferation (Bühler et al., 1998; Blum and Hammon, 2000). As a result of extended colostrum and transition milk feeding, intestinal epithelial growth was promoted by extended colostrum feeding in the same calves (data not shown), indicating that increased nutrient absorption due to greater epithelial development resulted in a higher GLP-1 concentration for the calves in C. Colostrum intake modifies GIT development and digestive and absorptive capacities in neonates, not only thorough provision of nutrients, minerals, vitamins, and energy but also due to effects of growth factors in various species, including calves (Blum and Hammon, 2000). In the present study, the intake of nutrients (fat, protein, lactose, and MUN) and presumably growth factors, such as IGF-1 or insulin, were different between treatments, which may be involved in GIT development. Plasma GLP-1 concentration was lower for CM than for C on d 3 after birth, indicating that intestinal growth by extended transition milk feeding was not sufficient to increase plasma GLP-1 concentration compared with that by extended colostrum feeding. In this study, plasma GLP-1 concentration was not different between treatments on $\mathrm{d} 1$ and 2 despite the difference in the nutrient intake among treatments. It has been shown that abomasal glucose and starch infusion did not stimulate GLP-1 secretion in cows (Relling and Reynolds, 2008; Larsen et al., 2010). Similarly, correlation was not observed between plasma glucose and GLP-1 concentrations for a 4 -h period after feeding on $\mathrm{d} 1$ and 3 in the present study. Previous studies (human model) reported that dietary proteins do not consistently elicit a response of glucagon-like peptide-2 (GLP-2), which is co-secreted with GLP-1 from the same cells (Xiao et al., 1999; Dubé and Brubaker, 2004). On the other hand, it was reported that receptors of free fatty acids, including short-, medium-, and long-chain fatty acids, are expressed on L-cells (Connor et al., 2015). Previous studies reported that GLP-2 (hence GLP-1) was secreted in response to fatty acids administered perorally in rats (Tappenden and McBurney, 1998), intraruminally in sheep (Elsabagh et al., 2017), and in the diet (Xiao et al., 1999) or directly to the duodenum (Feltrin et al., 2006) in healthy men. Further, Fukumori et al. (2012) reported that intravenous infusion of short-chain fatty acids stimulated GLP-1 secretion in newborn calves. However, fat intake was lower for $\mathrm{C}$ than for $\mathrm{M}$ in the present study. Therefore, greater GLP-1 concentra- tion for $\mathrm{C}$ than for the other treatment groups may be mainly attributed to promoted nutrient absorption from intestinal cells due to increased epithelial surface area rather than the direct effect of different nutrient intake between treatment diets on L-cells. As described above, GLP-2 is co-secreted with GLP-1 from intestinal L-cells in neonatal calves (Inabu et al., 2018). Future study is needed to identify the changes of GLP-2 in response to the treatments, which further verify the above speculations.

In the present study, plasma concentration of GLP-1 was positively correlated with that of insulin after feeding on $\mathrm{d} 3$ but not after feeding on $\mathrm{d} 1$. Therefore, it is possible that elevated plasma concentration of GLP-1 partially contributed to enhance insulin secretion via its insulinotropic action on d 3 after birth.

\section{CONCLUSIONS}

Our results indicate that extended colostrum feeding may increase plasma GLP-1 concentration on d 3 after birth, which may be the result of enhanced nutrient absorption from the intestine. In contrast, plasma glucose and insulin concentrations were decreased by prolonged colostrum feeding on d 1 after birth. However, differences between treatments were not observed on d 3 after birth despite the lower lactose content for colostrum and warrant further investigation to evaluate the longterm effect of extended colostrum feeding. These findings extend our understanding of the effects of different colostrum feeding durations on glucose homeostasis via insulin and GLP-1 secretion and may have implications for the improvement of calf performance.

\section{ACKNOWLEDGMENTS}

The authors are grateful for the funding support provided by Alberta Livestock and Meat Agency Ltd. (Edmonton, AB, Canada), Alberta Milk (Edmonton, AB, Canada), The Saskatoon Colostrum Co. Ltd. (Saskatoon, SK, Canada), the Natural Sciences and Engineering Research Council of Canada (Ottawa, ON, Canada), Dairy Farmers of Manitoba, Lallemand (Montreal, QC, Canada), SaskMilk (Regina, SK, Canada), BC Dairy Association (Vancouver, BC, Canada), and Westgen (Abbotsford, BC, Canada). The authors also thank the staff of the Dairy Research and Technology Centre (University of Alberta, Edmonton, AB, Canada) for their assistance with the animal experiment.

\section{REFERENCES}

Acitores, A., N. González, V. Sancho, L. Arnés, I. Valverde, W. J. Malaisse, and M. L. Villanueva-Peñacarrillo. 2005. Participation of protein kinases in the stimulant action of GLP-1 on 2-deoxy-D- 
glucose uptake by normal rat skeletal muscle. Horm. Metab. Res. $37: 275-280$.

Bittrich, S., C. Morel, C. Philipona, Y. Zbinden, H. M. Hammon, and J. W. Blum. 2002. Physiological traits in preterm calves during their first week of life. J. Anim. Physiol. Anim. Nutr. (Berl.) 86:185-198.

Blum, J. W. 2006. Nutritional physiology of neonatal calves. J. Anim. Physiol. Anim. Nutr. (Berl.) 90:1-11.

Blum, J. W., and H. M. Hammon. 2000. Colostrum effects on the gastrointestinal tract, and on nutritional, endocrine and metabolic parameters in neonatal calves. Livest. Prod. Sci. 66:1151-1159.

Bühler, C., H. Hammon, G. L. Rossi, and J. W. Blum. 1998. Small intestinal morphology in eight-day-old calves fed colostrum for different duration or only milk replacer and treated with long-R3insulin-like growth factor-I and growth hormone. J. Anim. Sci. $76: 758-765$.

Connor, E. E., C. M. Evock-Clover, M. P. Walker, T. H. Elsasser, and S. Kahl. 2015. Comparative physiology of glucagon-like peptide-2: Implications and applications for production and health of ruminants. J. Anim. Sci. 93:492-501.

Desjardins-Morrissette, M., J. K. van Niekerk, D. Haines, T. Sugino, M. Oba, and M. A. Steele. 2018. The effect of tube versus bottle feeding colostrum on immunoglobulin G absorption, abomasal emptying, and plasma hormone concentrations in newborn calves. J. Dairy Sci. 101:4168-4179.

Dubé, P. E., and P. L. Brubaker. 2004. Nutrient, neural and endocrine control of glucagon-like peptide secretion. Horm. Metab. Res. $36: 755-760$.

Edwards, C. M. B., A. V. Edwards, and S. R. Bloom. 1997. Cardiovascular and pancreatic endocrine responses to glucagon-like peptide-1 (7-36) amide in the conscious calf. Exp. Physiol. 82:709-716.

Elsabagh, M., Y. Inabu, T. Sugino, and T. Obitsu. 2017. Response of plasma glucagon-like peptide-2 to feeding pattern and intraruminal administration of volatile fatty acids in sheep. Domest. Anim. Endocrinol. 60:31-41.

Faulkner, A. 1991. Sensitivity of serum insulin concentrations to glucagon-like peptide 1 (7-36) amide in sheep. Biochem. Soc. Trans. 19:311S.

Feltrin, K. L., M. Patterson, M. A. Ghatei, S. R. Bloom, J. H. Meyer, M. Horowitz, and C. Feinle-Bisset. 2006. Effect of fatty acid chain length on suppression of ghrelin and stimulation of PYY, GLP-2 and PP secretion in healthy men. Peptides 27:1638-1643.

Fowden, A. L. 1997. Comparative aspects of fetal carbohydrate metabolism. Equine Vet. J. Suppl. 24:19-25.

Fukumori, R., T. Mita, T. Sugino, T. Obitsu, and K. Taniguchi. 2012. Plasma concentrations and effects of glucagon-like peptide-1 (7-36) amide in calves before and after weaning. Domest. Anim. Endocrinol. 43:299-306.

Girard, J. 1986. Metabolic adaptations to changes of nutrition at birth. Biol. Neonate 50:237-258.

Girard, J., P. Ferré, J. P. Pégorier, and P. H. Duée. 1992. Adaptions of glucose and fatty acid metabolism during perinatal period and suckling-weaning transition. Physiol. Rev. 72:507-562.

Grosvenor, C. E., M. F. Picciano, and C. R. Baumrucker. 1993. Hormones and growth factors in milk. Endocr. Rev. 14:710-728.

Hadorn, U., H. Hammon, R. M. Bruckmaier, and J. W. Blum. 1997. Delaying colostrum intake by one day has important effects on metabolic traits and on gastrointestinal and metabolic hormones in neonatal calves. J. Nutr. 127:2011-2023.

Hammon, H., and J. W. Blum. 1997. Prolonged colostrum feeding enhances xylose absorption in neonatal calves. J. Anim. Sci. 75:2915-2919.

Hammon, H. M., and J. W. Blum. 1998. Metabolic and endocrine traits of neonatal calves are influenced by feeding colostrum for different durations or only milk replacer. J. Nutr. 128:624-632.

Hammon, H. M., J. Steinhoff-Wagner, J. Flor, U. Schönhusen, and C. C. Metges. 2013. Lactation Biology Symposium: Role of colostrum and colostrum components on glucose metabolism in neonatal calves. J. Anim. Sci. 91:685-695.
Hammon, H. M., I. A. Zanker, and J. W. Blum. 2000. Delayed colostrum feeding affects IGF-I and insulin plasma concentrations in neonatal calves. J. Dairy Sci. 83:85-92.

Holz, G. G. IV, W. M. Kühtreiber, and J. F. Habener. 1993. Pancreatic beta-cells are rendered glucose-competent by the insulinotropic hormone glucagon-like peptide-1(7-37). Nature 361:362-365.

Inabu, Y., A. Fischer, Y. Song, L. L. Guan, M. Oba, M. A. Steele, and T. Sugino. 2018. The effect of delayed colostrum feeding on plasma concentrations of glucagon-like peptide 1 and 2 in newborn calves. J. Dairy Sci. 101:6627-6631.

Inabu, Y., A. Saegusa, K. Inouchi, S. Koike, M. Oba, and T. Sugino. 2017. Plasma concentrations of glucagon-like peptide 1 and 2 in calves fed calf starters containing lactose. J. Dairy Sci. 100:93619371.

Koldovský, O. 1989. Search for a role of milk-borne biologically active peptides for the suckling. J. Nutr. 119:1543-1551.

Larsen, M., A. E. Relling, C. K. Reynolds, and N. B. Kristensen. 2010. Effect of abomasal glucose infusion on plasma concentrations of gut peptides in periparturient dairy cows. J. Dairy Sci. 93:5729-5736.

Luque, M. A., N. González, L. A. Márquez Acitores, A. Redondo, M. Morales, I. Valverde, and M. L. Villanueva-Peñacarrillo. 2002. Glucagon-like peptide-1 (GLP-1) and glucose metabolism in human myocytes. J. Endocrinol. 173:465-473.

Nussbaum, A., G. Schiessler, H. M. Hammon, and J. W. Blum. 2002. Growth performance and metabolic and endocrine traits in calves pair-fed by bucket or by automate starting in the neonatal period. J. Anim. Sci. 80:1545-1555.

O'Halloran, D. J., G. C. Nikou, B. Kreymann, M. A. Ghatei, and S. R. Bloom. 1990. Glucagon like peptide-1 (7-36)-NH2: A physiological inhibitor of gastric acid secretion in man. J. Endocrinol. 126:169-173

Rauprich, A. B. E., H. M. Hammon, and J. W. Blum. 2000. Effects of feeding colostrum and a formula with nutrient contents as colostrum on metabolic and endocrine traits in neonatal calves. Biol. Neonate 78:53-64.

Relling, A. E., and C. K. Reynolds. 2008. Abomasal infusion of casein, starch and soybean oil differentially affect plasma concentrations of gut peptides and feed intake in lactating dairy cows. Domest. Anim. Endocrinol. 35:35-45.

Roy, J. H. B. 1980. Factors affecting susceptibility of calves to disease. J. Dairy Sci. 63:650-664.

Sancho, V., M. V. Trigo, N. González, I. Valverde, W. J. Malaisse, and M. L. Villanueva-Peñacarrillo. 2005. Effects of glucagon-like peptide-1 and exendins on kinase activity, glucose transport and lipid metabolism in adipocytes from normal and type-2 diabetic rats. J. Mol. Endocrinol. 35:27-38.

Sancho, V., M. V. Trigo, A. Martín-Duce, N. Gonzalez, A. Acitores, L. Arnés, I. Valverde, W. J. Malaisse, and M. L. Villanueva-Peñacarrillo. 2006. Effect of GLP-1 on D-glucose transport, lipolysis and lipogenesis in adipocytes of obese subjects. Int. J. Mol. Med. 17:1133-1137.

Steinhoff-Wagner, J., S. Görs, P. Junghans, R. M. Bruckmaier, E. Kanitz, C. C. Metges, and H. M. Hammon. 2011a. Intestinal glucose absorption but not endogenous glucose production differs between colostrum- and formula-fed neonatal calves. J. Nutr. 141:48-55.

Steinhoff-Wagner, J., S. Görs, P. Junghans, R. M. Bruckmaier, E. Kanitz, C. C. Metges, and H. M. Hammon. 2011b. Maturation of endogenous glucose production in preterm and term born calves. J. Dairy Sci. 94:5111-5123.

Sugino, T., Y. Hasegawa, Y. Kurose, M. Kojima, K. Kangawa, and Y. Terashima. 2004. Effects of ghrelin on food intake and neuroendocrine function in sheep. Anim. Reprod. Sci. 82-83:183-194.

Tappenden, K. A., and M. I. McBurney. 1998. Systemic short-chain fatty acids rapidly alter gastrointestinal structure, function, and expression of early response genes. Dig. Dis. Sci. 43:1526-1536.

Xiao, Q., R. P. Boushey, D. J. Drucker, and P. L. Brubaker. 1999. Secretion of the intestinotropic hormone glucagon-like peptide 2 is differentially regulated by nutrients in humans. Gastroenterology 117:99-105. 